\begin{tabular}{|l|l|l||}
\hline \multicolumn{2}{|c|}{ PublisherInfo } \\
\hline \hline PublisherName & $:$ & BioMed Central \\
\hline \hline PublisherLocation & $:$ & London \\
\hline \hline PublisherImprintName & $:$ & BioMed Central \\
\hline \hline
\end{tabular}

\title{
Muscle checkpoint
}

\begin{tabular}{|l|l|l||}
\hline \multicolumn{2}{|c|}{ ArticleInfo } \\
\hline \hline ArticleID & $:$ & 4628 \\
\hline \hline ArticleDOI & $:$ & $10.1186 /$ gb-spotlight-20021106-02 \\
\hline \hline ArticleCitationID & $:$ & spotlight-20021106-02 \\
\hline \hline ArticleSequenceNumber & $:$ & 294 \\
\hline \hline ArticleCategory & $:$ & Research news \\
\hline ArticleFirstPage & $:$ & 1 \\
\hline \hline ArticleLastPage & $:$ & 2 \\
\hline \hline & & RegistrationDate : 2002-11-6 \\
\hline ArticleHistory & $:$ & OnlineDate \\
\hline \hline ArticleCopyright & $:$ & BioMed Central Ltd2002-11-6 \\
\hline \hline ArticleGrants & $:$ & \\
\hline \hline ArticleContext & $:$ & 130593311 \\
\hline \hline
\end{tabular}




\section{Jonathan B Weitzman}

Email: jonathanweitzman@hotmail.com

Cell-cycle checkpoints ensure that damaged DNA is repaired prior to cell division. In an Advanced Online Publication in Nature Genetics, Puri et al. describe characterization of a differentiation checkpoint that operates in muscle cells in response to DNA-damaging agents (Nature Genetics, 4 November 2002; DOI:10.1038/ng1023). Treatment of the C2C12 myoblast cell line with different genotoxic drugs (cisplatin, etoposide, or methyl methane sulphate, MMS) blocked the progression of myogenic differentiation and induced cell-cycle arrest. Cisplatin and MMS prevented the transcriptional activity of the myogenic factor MyoD. This inhibition involves the c-Abl tyrosine kinase, but not the p53 or c-Jun proteins that have also been implicated in the DNA-damage response. Puri et al. show that $\mathrm{MyoD}$ is a direct target of the c-Abl kinase and that phosphorylation of MyoD is critical for inhibition by genotoxic drugs.

\section{References}

1. The DNA damage response: putting checkpoints in perspective.

2. Nature Genetics, [http://www.nature.com/ng] 